\title{
Agrobacterium-mediated transformation systems of Primula vulgaris
}

\author{
Sadiye Hayta ${ }^{1,2^{*}}$, Mark A. Smedley ${ }^{2}$, Jinhong Li ${ }^{1,3}$, Wendy A. Harwood ${ }^{2}$ and Philip M. Gilmartin ${ }^{1,3}$
}

\begin{abstract}
Background: Genetic transformation is a valuable tool and an important procedure in plant functional genomics contributing to gene discovery, allowing powerful insights into gene function and genetically controlled characteristics. Primulaceae species provide one of the best-known examples of heteromorphic flower development, a breeding system which has attracted considerable attention, including that of Charles Darwin. Molecular approaches, including plant transformation give the best opportunity to define and understand the role of genes involved in floral heteromorphy in the common primrose, Primula vulgaris, along with other Primula species.

Results: Two transformation systems have been developed in P. vulgaris. The first system, Agrobacterium-mediated vacuum infiltration of seedlings, enables the rapid testing of transgenes, transiently in planta. GUS expression was observed in the cotyledons, true leaves, and roots of Primula seedlings. The second system is based on Agrobacterium tumefaciens infection of pedicel explants with an average transformation efficiency of $4.6 \%$. This transformation system, based on regeneration and selection of transformants within in vitro culture, demonstrates stable transgene integration and transmission to the next generation.

Conclusion: The two transformation systems reported here will aid fundamental research into important traits in Primula. Although, stable integration of transgenes is the ultimate goal for such analyses, transient gene expression via Agrobacterium-mediated DNA transfer, offers a simple and fast method to analyse transgene functions. The second system describes, for the first time, stable Agrobacterium-mediated transformation of Primula vulgaris, which will be key to characterising the genes responsible for the control of floral heteromorphy.
\end{abstract}

Keywords: Primula vulgaris, Heteromorphy, Agrobacterium, Transformation, Stable, Transient, Infiltration

\section{Background}

Genetic transformation is an important technique for the in vivo analysis of gene function, especially in relation to plant development through gene over-expression, gene knock-out, and gene structure function analyses. Additionally, the function of genes isolated using map-based cloning of mutant alleles has been confirmed by functional complementation using genetic transformation [1]. Agrobacterium tumefaciens-mediated transformation is a suitable technique to conduct such complementation analyses, offering defined integration of transgenes and single or low-copy number integration into transcriptionally active regions of the chromosome [2, 3]. Although

\footnotetext{
${ }^{*}$ Correspondence: sadiye.hayta@jic.ac.uk

2 John Innes Centre, Norwich Research Park, Norwich NR4 7UH, UK

Full list of author information is available at the end of the article
}

stable integration of physiologically active and regulated transgenes is the ultimate goal of such functional studies, transient gene expression via Agrobacterium-mediated DNA transfer into different plant tissues offers an alternative route for the rapid analysis of transgene functions, which is also amenable to high-throughput analysis [4]. Transient systems like biolistic bombardment, protoplast fusion and Agrobacterium-mediated transient transformation each have advantages and disadvantages depending on the specific research requirements. Among these transformation assays tobacco leaf infiltration mediated by $A$. tumefaciens is widely appreciated due to its easy operation and high transformation efficiency [5].

Transgenic plants are usually produced by methods that include the transformation of individual plant cells followed by regeneration of whole plants from those transformed cells. This has the advantage of minimising 
the opportunity for chimeric transgenics, but the difficulty of plant regeneration from transformation-susceptible tissues is one of the key challenges in the production of transgenic plants [6]. Primula species are particularly recalcitrant to in vitro regeneration and this has limited the development of transformation systems in this genus. Until recently, only in vitro grown seedlings delivered explant materials that regenerated in tissue culture in various Primula species [7-11]. In P. vulgaris, in vitro regeneration was obtained only by destruction of the parent plant [12] and from pedicel explants [13]. Recently an efficient protocol was developed for in vitro regeneration of $P$. vulgaris via indirect organogenesis from adult leafderived explants without any seasonal limitations [14].

Following the recent identification of the Primula $S$ locus that controls floral heteromorphy in $P$. vulgaris [15], the development of transformation systems for $P$. vulgaris is particularly important for the functional characterisation of the genes involved in the floral heteromorphy and self-incompatibility. Primulaceae species provide one of the best known examples of heteromorphic flower development; a breeding system has attracted considerable attention, including that of Charles Darwin $[16,17]$. The common primrose, $P$. vulgaris, along with the majority of the approx. 450 species of Primula exhibit floral heteromorphy in which different individuals develop one of two possible forms of flower, known as pin and thrum. Both flower types are hermaphrodite and exhibit reciprocal positions of male and female reproductive structures, which together with an associated self-incompatibility system, promote outcrossing and inhibit self-pollination $[18,19]$.
Transgenic approaches give the best opportunity to define, understand and dissect the role of the genes involved in the control of floral heteromorphy in the common primrose, $P$. vulgaris, and other Primula species. The underlying genes responsible for these different flower forms control anther position, style length and pollen size, and are clustered within the $S$ locus [20]. The recent isolation of the $S$ locus supergene cluster, and its constituent genes [15], provides opportunities for their exploitation within crops following their functional characterisation. Potentially, transformation techniques for Primula species may provide opportunities for breeders to improve or create more horticultural varieties using molecular genetic knowledge.

Primula transformation is key to the important task of the functional definition of genes within the $S$ locus [18]. In this paper, we describe two methods of genetic transformation for $P$. vulgaris. The first, vacuum infiltration of in vitro grown seedlings enables transient gene expression analysis. The second, transformation and in vitro regeneration of stably transformed $P$. vulgaris plants is key to unravelling the underlying mechanisms of $S$ locus gene function.

\section{Results}

Our aim in this study was to establish a rapid transient system and reliable stable transformation system for P. vulgaris. To enable this, one of the first steps was to assess and build a reporter binary vector to be used for the optimisation of our transformation experiments (Fig. 1).

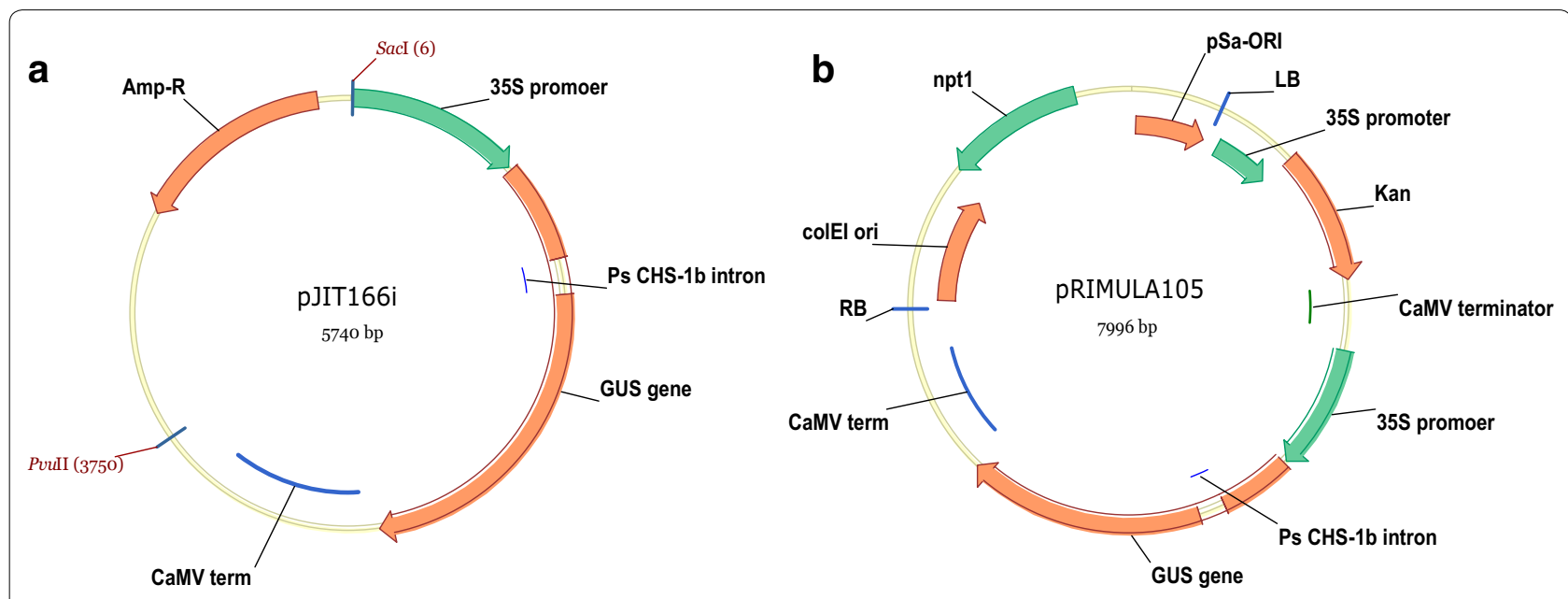

Fig. 1 a The cloning vector pJIT166i containing the CaMV35S promoter driving the UidA (GUS) gene containing the Pisum sativum CHS-1b intron. $\mathbf{b}$ The UidA (GUS) reporter construct PRIMULA105 which was developed for the initiation and optimisation of P. vulgaris transformation 


\section{Selection of CaMV 35 S promoter/UidA reporter gene cassette}

In initial biolistic transient expression experiments, we assessed different 35S-UidA cassettes, and expression of the UidA reporter gene was visualised by a $\beta$-glucuronidase (GUS) assay. Details of the different constructs are provided in "Materials and methods" section. Blue foci could not be seen in the leaf sections bombarded with pBRACT104 [21] containing 35S-UidA with the Ricinus communis CAT1 intron. However, GUS foci were seen in the leaf material bombarded with pJIT161 [22] containing the 35S-UidA gene without an intron (Fig. 2a). Material bombarded with pJIT166i containing the Pisum sativum CHS-1b intron produced more GUS foci and higher GUS accumulation was observed (Fig. 2b). These observations demonstrate that the CaMV $35 S$ promoter was active in P. vulgaris, that the UidA reporter gene was suitable for use in the optimisation of Primula transformation and that $P$. vulgaris processed the CHS intron1b within the UidA gene. The absence of GUS activity using 35S-UidA CAT1 intron cassette suggest that $P$. vulgaris cannot efficiently process the $R$. communis CAT1 intron.

\section{Agrobacterium tumefaciens infiltration of Primula vulgaris seedlings as a transient assay system}

Having demonstrated functionality of the 35S-UidA CHS intron $1 b$ cassette, we cloned this into pBRACT102 to create a binary vector named pRIMULA105 for Agrobacterium tumefaciens mediated transformation assays in $P$. vulgaris. GUS activity was observed in the cotyledons, true leaves, and some root parts of $P$. vulgaris seedlings after infiltration with $A$. tumefaciens AGL1 containing pRIMULA105 and in vitro cultured on solid MS medium (Fig. 3). Optimal GUS activity was seen in seedlings infiltrated at the two-true leaf stage, where the largest of the true leaves had reached approximately $0.5 \mathrm{~cm}^{2}(15$ seedlings out of 15). A considerable decrease or no GUS activity was seen in seedlings infiltrated after the fourtrue leaf stage or later (2 seedlings out of 15$)$.

\section{Stable Agrobacterium tumefaciens- mediated Primula vulgaris transformation \\ Selection of best explant for stable transformation systems}

Leaf material as described in Hayta et al. [14] and pedicel explants were compared in our first experiments. When the leaf-derived explant was used, sensitivity to Agrobacterium was observed and the elimination of Agrobacterium proved difficult when compared to pedicel derived material (data not shown). Therefore, subsequent work concentrated on the use of pedicel explants.

\section{Explant pre-culture prior to inoculation with Agrobacterium tumefaciens}

Pre-culturing explants for 2 weeks prior to inoculation with $A$. tumefaciens was found to be crucial for explant viability and subsequent shoot regeneration. Explants inoculated with $A$. tumefaciens on the day of isolation often resulted in a hypersensitive response showing browning and a loss of viability, ultimately resulting in explant death. Overgrowth of these explants by $A$. tumefaciens was common and latent bacterial contamination was also observed. Explants pre-cultured for 2 weeks prior to $A$. tumefaciens inoculation began to swell and callus prior to inoculation. Explants suffering with latent bacterial contamination were identified after 2 weeks pre-culture and discarded. Pre-cultured explants showed reduced overgrowth from $A$. tumefaciens and less sensitivity to the bacterial treatment. The viability of the explant receiving the pre-culture treatment was improved. GUS activity on pre-treated pedicel explants was $68 \%$ after 4 weeks, this was reduced to $3.3 \%$
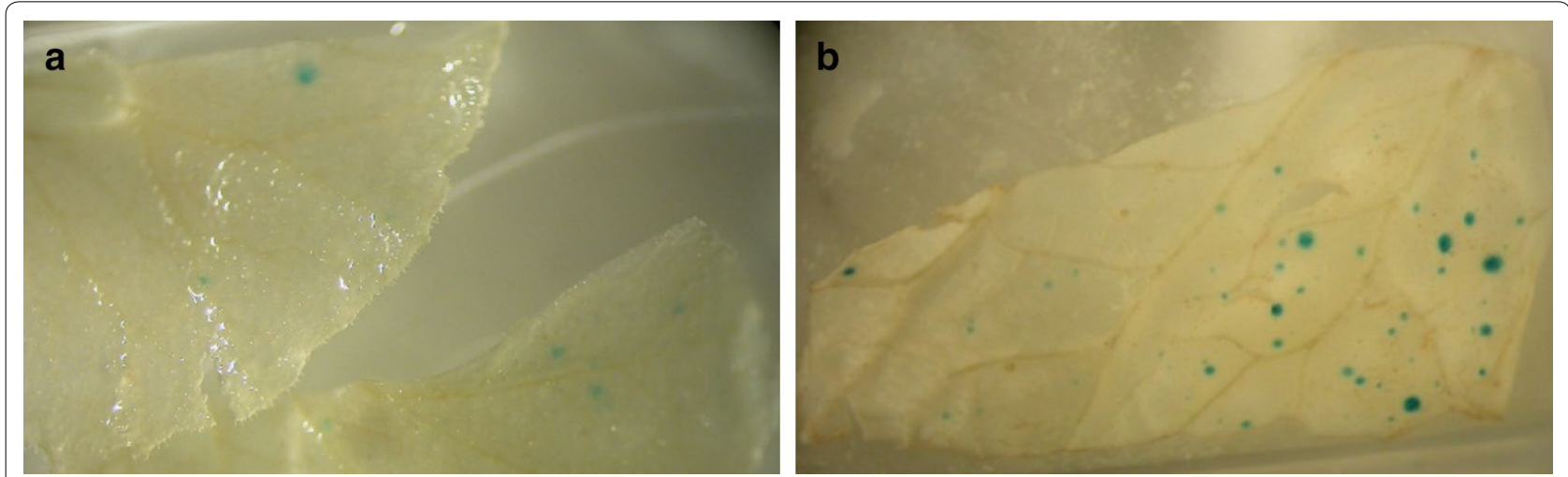

Fig. 2 Transient GUS expression in P. vulgaris seedling leaves bombarded with: a pJIT161 containing the UidA (GUS) gene without an intron, b pJIT161i containing the UidA (GUS) gene with the Pisum sativum CHS-1b intron 


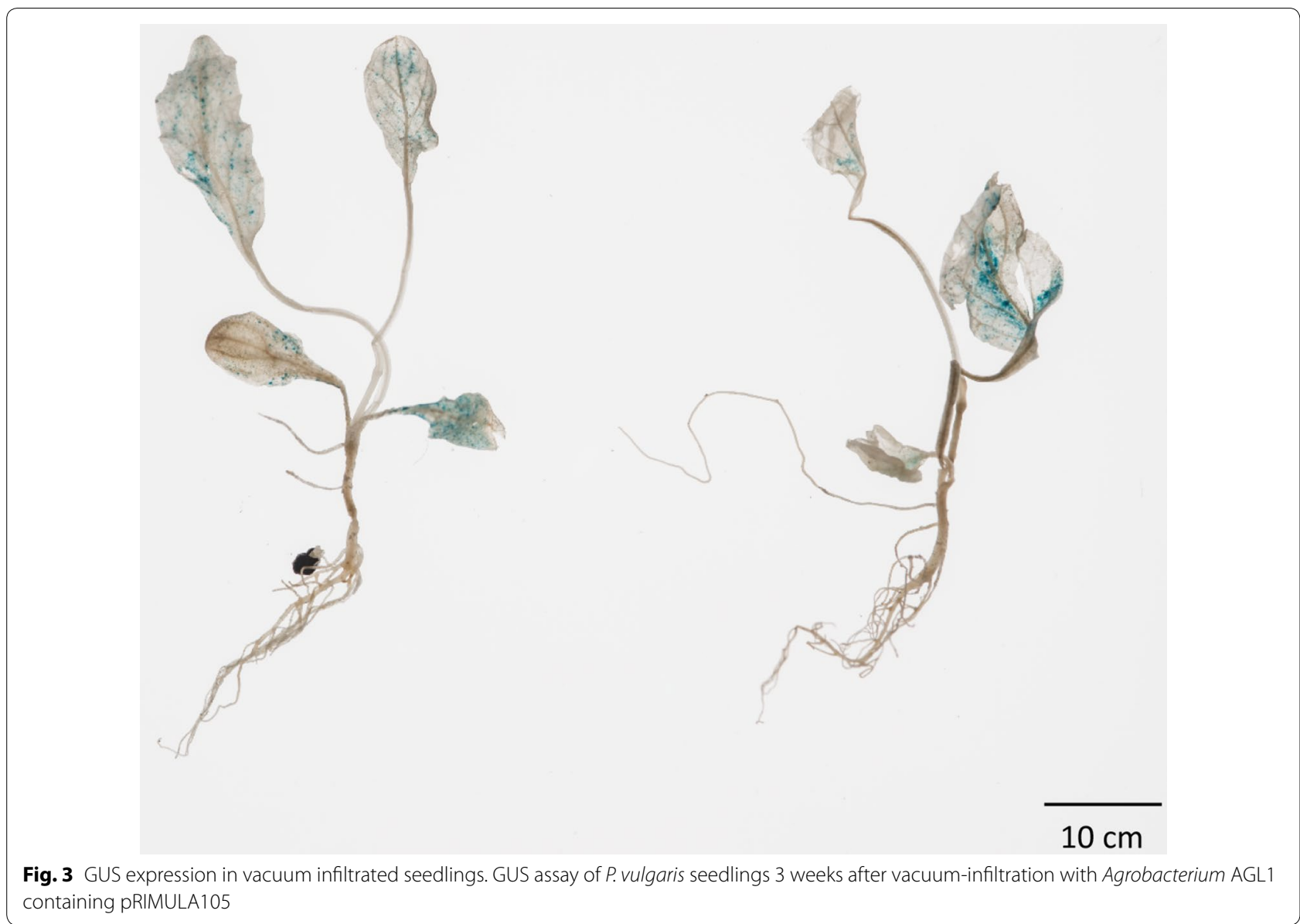

on non-pre-cultured explants mainly because of $A$. tumefaciens overgrowth.

\section{Optimisation of selection conditions for $P$. vulgaris}

Sensitivity to the selective agent kanamycin was determined by including different concentrations of kanamycin $\left(0,100,125,150,200 \mathrm{mg} \mathrm{L}^{-1}\right)$ in PCI medium and visually assessing plant material after 3 weeks culture. Kanamycin at $200 \mathrm{mg} \mathrm{L}^{-1}$ completely inhibited callus growth and caused severe necrosis. On PCI medium lacking kanamycin, $100 \%$ callus induction was obtained from the cultured explants. The inclusion of $100 \mathrm{mg} \mathrm{L}^{-1}$ kanamycin moderately checked callus growth. Inclusion of $150 \mathrm{mg} \mathrm{L}^{-1}$ kanamycin inhibited callus growth and cause minor necrosis. Kanamycin at a concentration of $125 \mathrm{mg} \mathrm{L}^{-1}$ checked callus growth but did not cause necrosis. Therefore, a concentration of $125 \mathrm{mg} \mathrm{L}^{-1}$ kanamycin was deemed to be a suitable level of selection for subsequent transformation experiments.

\section{Inclusion of $\mathrm{AgNO}_{3}$ in co-cultivation medium}

The inclusion of $\mathrm{AgNO}_{3}$ in co-cultivation medium had a dramatic effect on shoot regeneration and the percentage of explants showing GUS expression. A reduction of explants overgrown by $A$. tumefaciens was also observed. $\mathrm{AgNO}_{3}$ was included at concentrations of 5, 10 and $20 \mu \mathrm{M}$ in co-cultivation medium. Calli showing shoot regeneration increased with the addition of $\mathrm{AgNO}_{3}$ to co-cultivation medium, except at the higher concentration of $20 \mu \mathrm{M}$ (Fig. 4). The percentage of explants showing GUS activity increased when $\mathrm{AgNO}_{3}$ was included in co-cultivation medium compared to medium without $\mathrm{AgNO}_{3}$ (Fig. 4). Inclusion of $\mathrm{AgNO}_{3}$ at a concentration of $10 \mu \mathrm{M}$ had the greatest effect on shoot regeneration and calli showing GUS activity compared to all other treatments, $3 \%$ and $18 \%$ respectively. Strong GUS activity was seen in the compact calli stained after 8 weeks in vitro culture (Fig. 5a). Supplementation of PCI media with additional copper sulphate $\left(\mathrm{CuSO}_{4}\right)$ had no effect on shoot regeneration, whether combined with or without $\mathrm{AgNO}_{3}$ (data not shown).

\section{Transformation efficiencies}

With a combination of 2 weeks' pre-culture, inclusion of $\mathrm{AgNO}_{3}$ at $10 \mu \mathrm{M}$ in the co-cultivation medium and selection set at $125 \mathrm{mg} \mathrm{L}^{-1}$ kanamycin during callus induction 


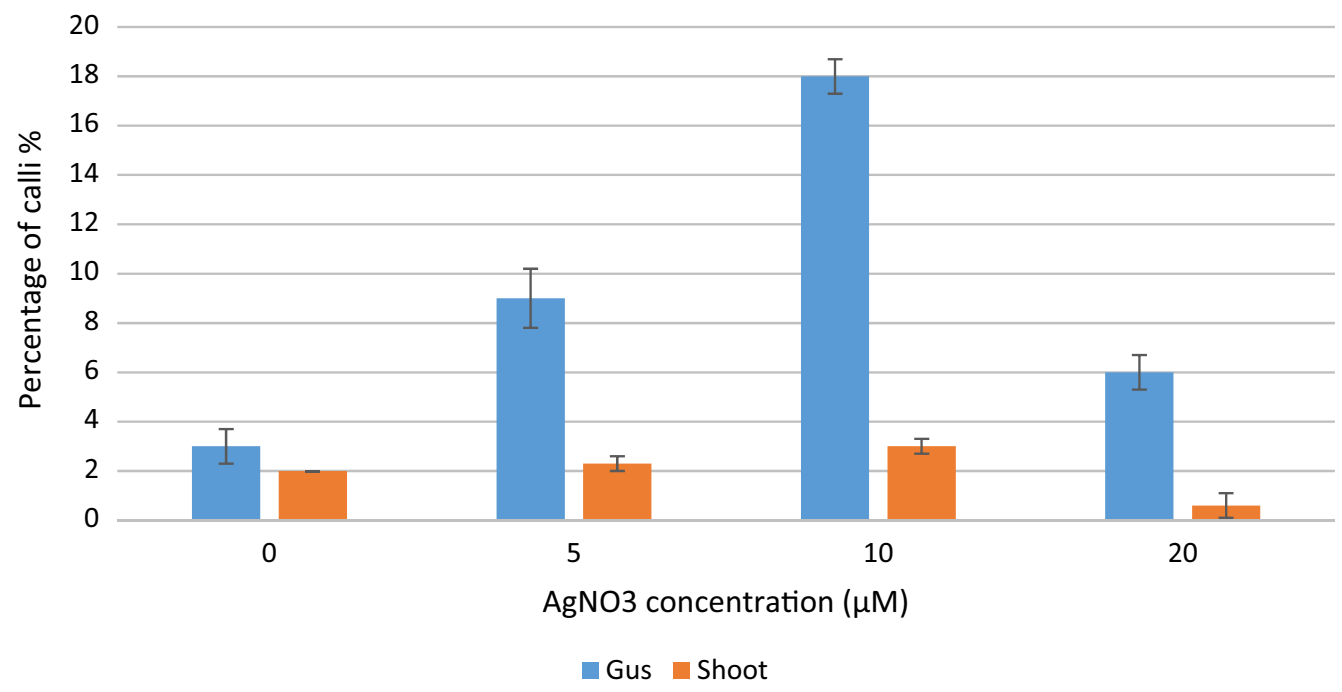

Fig. 4 Effect of different concentrations of $\mathrm{AgNO}_{3}$, included in co-cultivation medium, on percentage of calli showing GUS expression (blue) and shoot regeneration (orange) of Primula vulgaris. Percentage of calli producing shoots from three replicates with a total of 45 calli per treatment $(n=45)$. Error bars show the SD from mean values of shoot production and GUS expression

and shoot regeneration; $37.8 \%$ of pedicel explants developed green organogenic calli. Three hundred and two pedicel explants inoculated with $A$. tumefaciens containing pRIMULA105 produced 55 rooted putative transformants on WPM with $125 \mathrm{mg} \mathrm{L}^{-1}$ kanamycin. PCR analysis identified 14 of these to contain the NptII gene, giving an overall transformation efficiency of $4.6 \%$. All samples were shown to be free of $A$. tumefaciens contamination by VirD2 PCR analysis. A positive P. vulgaris Actin gene PCR control proved all DNA extractions were of PCR amplifiable quality (data not shown). A subset of the NptII PCR positive plants were GUS stained and showed strong GUS activity (5b). Twelve independent transgenic lines displaying GUS expression are shown in Fig. 5c. Subsequently, increasing the kanamycin level to $135 \mathrm{mg} \mathrm{L}^{-1}$ in rooting medium (Fig. $5 \mathrm{~d}$ ) proved effective in reducing the number of escapes without affecting the overall transformation efficiency. It was observed that non-transformed plantlets (escapes) did not produce root hairs when grown on rooting medium with kanamycin selection, whereas transformed plantlets displayed strong roots with an abundance of root hair (confirmed by PCR analysis).

\section{Analysis of transgene inheritance}

To test that the inherited transgene's expression was stable in the subsequent generation, $\mathrm{T}_{1}$ seed from five outcrossed $\mathrm{T}_{0}$ lines were germinated on kanamycin containing MS medium. Kanamycin resistant seedlings were obtained from each of the five lines, demonstrating stable transgene expression in the next generation (data not shown). To further address stable inheritance of the transgene, we used Southern analysis of the progeny of one of these transgenic lines. As described above, P. vulgaris plants produce either pin or thrum form flowers. A thrum background transgenic $\mathrm{T}_{0}$ plant was outcrossed to a pin background non-transgenic plant to produce $\mathrm{T}_{1}$ seeds and the progeny grown in order to confirm inheritance of the transgene in the next generation. Transgene inheritance in the $\mathrm{T}_{1}$ progeny was confirmed by NptII PCR analysis. Samples were determined to be free of $A$. tumefaciens contamination by the lack of an amplification product from the VirD2 PCR, alongside control PCR amplifications using the $P$. vulgaris Actin gene. Of the 54 $\mathrm{T}_{1}$ plants tested, PCR analysis confirmed that 28 of them, approximately $50 \%$, had inherited the NptII selection gene. This demonstrates stable transgene transmission to the next generation with a Mendelian inheritance ratio of $1-1$ and suggests transgene insertion at a single locus.

\section{Southern blot hybridization}

To further confirm the transformation of the $\mathrm{T}_{0}$ line and the $\mathrm{T}_{1}$ progeny, southern blot analysis was performed on a subset of four NptII PCR positive progeny plants (Fig. 6). A single transgene insertion was observed in the $\mathrm{T}_{0}$ plant and its four $\mathrm{T}_{1}$ progeny reaffirming the previous PCR segregation data. No hybridisation signal was observed in the non-transformed $P$. vulgaris negative control. These results confirm the integration of the NptII gene into the $P$. vulgaris genome at a single locus and prove transgene inheritance to the next generation. 


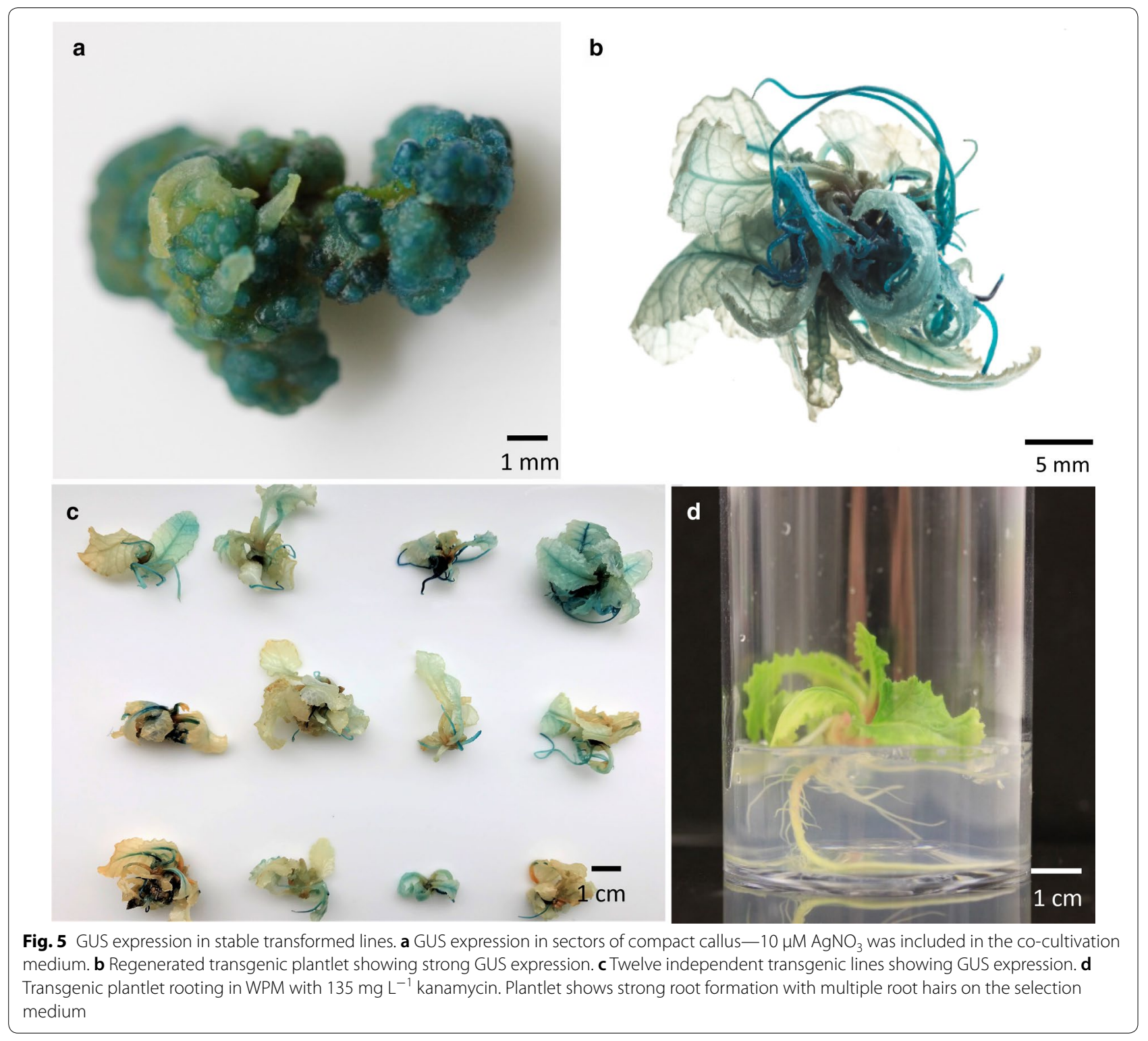

\section{Discussion}

We have developed two transformation systems for $P$. vulgaris. The first method involves the infiltration of Primula seedlings for transient gene expression studies. The use of infiltration of seedlings by $A$. tumefaciens was described as a simple transient expression in Arabidopsis thaliana [5], and called FAST "Fast Agromediated Seedling Transformation". There are only a few species for which FAST methods are available. In the model plant $A$. thaliana seedling infiltration has been used to express a wide variety of genes driven by many different promoters in A. thaliana seedling cotyledons [5]. For the model legume Medicago truncatula, seedling infiltration was developed and has provided a wide range of opportunities for genetic analysis [6]. A recent adaptation of the FAST method was used in transient overexpression experiments in Catharanthus roseus in order to study secondary metabolism [23]. Transient gene silencing was performed by injecting $P$. forbesii with a virus induced gene silencing (VIGS) vector [24], however, this methodology has limited scope when compared to the opportunities offered by FAST, such as over expression, promoter testing and RNAi [5]. Transient gene expression systems used in functional genetic assays allow rapid gene characterization with lower inputs than creating stable transformed plants, especially if the plants have long generation cycles like $P$. vulgaris $[25,26]$. This transient expression system, 
a

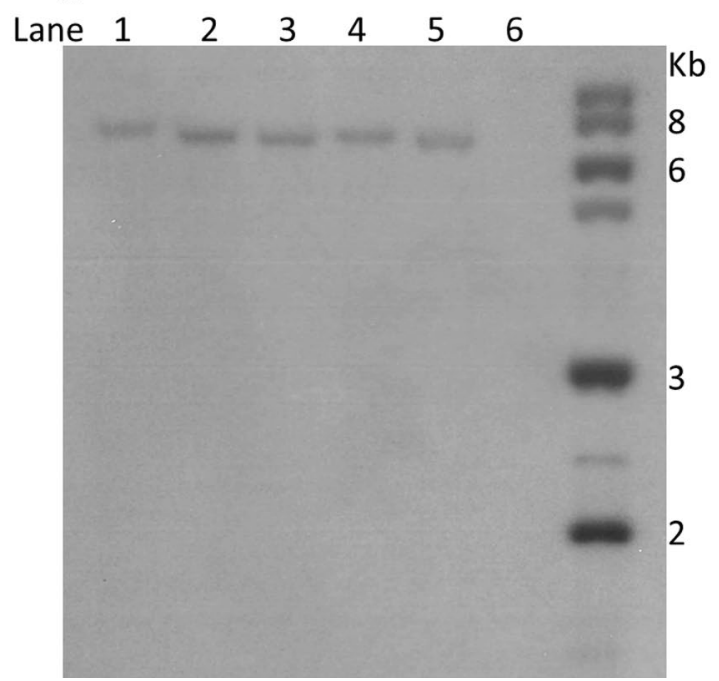

b

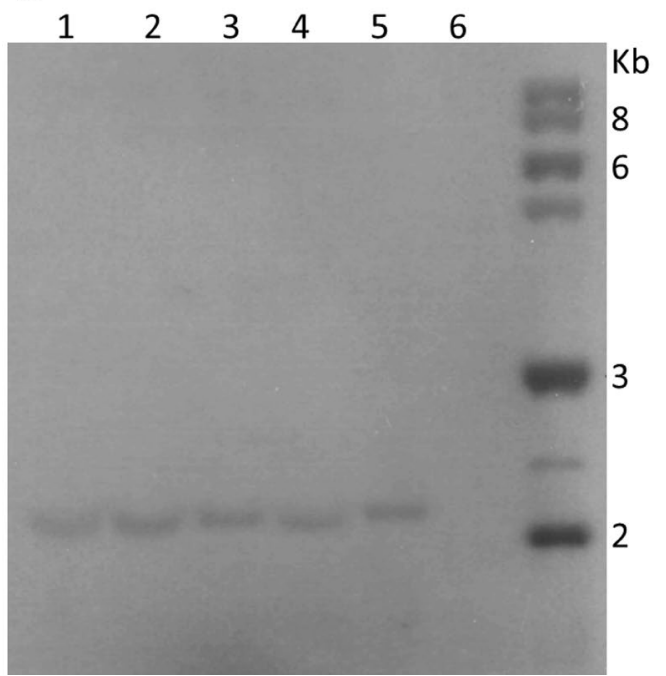

Fig. 6 Southern analysis, using nptll probe, showing transgene inheritance. Genomic DNA digested with restriction enzyme a Hindlll and $\mathbf{b}$ EcoRI. Lanes 1-4,T1 generation transgenic plants, Lane 5, parental T0 primary transgenic plant. Lane 6, WT control

when compared with a stable tissue-culture-based stable transformation method, is technically easier and faster, as it does not require tissue culture-based regeneration procedures, although it does not routinely lead to germline transformation which is important for some studies. The second method describes, for the first time, stable A. tumefaciens-mediated transformation of $P$. vulgaris and enables stable transgene integration and transmission to the next generation. Transgene transmission followed a Mendelian inheritance ratio of $1: 1$ as expected in an obligate outcrossing species such as $P$. vulgaris. Stable expression of the NptII transgene was observed in the next generation as assessed by kanamycin resistance in $\mathrm{T}_{1}$ seedlings.

Primulaceae species provide the best-known examples of heteromorphic flower development, and as such, offer the opportunity to be able to define and understand the role of genes involved in floral heteromorphy $[15,27]$. P. vulgaris plants either produce pin form flowers or thrum form flowers and crosses only occur between these two different forms. The underlying genes responsible for these different flower forms control anther position, style length and pollen size, and are clustered within the $S$ locus [15]. Improvements in large scale DNA sequencing has expedited the molecular characterisation of floral heteromorphy in Primula and other species $[15,24,28]$. Recently, the Primula $S$ locus was shown to be a supergene comprising of a tightly linked cluster of five thrum-specific genes, spanning a 278-kb sequence that is absent in plants producing the pin flower form [15]. P. vulgaris transformation will prove the key to ascribing gene functionality to the different genes within the $S$ locus supergene,

Many factors may affect the genetic transformation efficiency of plants. One crucial factor is the regeneration potential of the target material [6]. Primula species are particularly recalcitrant to in vitro regeneration and this has limited the development of transformation systems in Primula species. In P. vulgaris in vitro regeneration was obtained only by destruction of the parent plant [12] and from pedicel explants [13]. An efficient protocol was developed for in vitro regeneration of $P$. vulgaris via indirect organogenesis from adult leaf-derived explants without seasonal limitations [14]. Although, leaf-derived explants gave efficient regeneration, they were found to not be suitable for stable transformation because of their sensitivity to bacterial treatment and overgrowth from $A$. tumefaciens. To date, there are no published stable transformation studies in species of the Primulaceae.

Another important factor affecting transformation efficiency is the use of an effective selective agent that inhibits the development of non-transformed cells and permits the growth of transformed tissues. The selective agent concentration in culture medium can influence shoot regeneration and high concentrations may promote adverse effects on the organogenic potential of plant material. The most common selectable marker genes used in plant transformation vectors include constructs providing resistance to antibiotics such as kanamycin and hygromycin B and the Bar gene that allows the growth of plant cells in the presence of herbicides such as phosphinothricin (PPT), bialaphos or similar compounds. 
The neomycin phosphotransferase II (NptII) gene has proven to be the most widely applicable and has been used in most transformation procedures for dicotyledonous plants. The NptII gene confers resistance to aminoglycoside antibiotics kanamycin, neomycin and G-418, of which, kanamycin is the most used selective agent. Of the three major selection systems, the NptII gene and kanamycin selection seemed the most appropriate to initially use with $P$. vulgaris. Kanamycin at a level of $125 \mathrm{mg} \mathrm{L}^{-1}$ inhibited the growth of non-transformed cells while enabling transformed cells to regenerate from pedicel callus explants. As explants regenerated and grew they were moved onto rooting medium with level of kanamycin to $135 \mathrm{mg} \mathrm{L}^{-1}$. Maintaining explants for some additional 2-3 weeks on this selective rooting medium reduced the average number of escapes to around $12 \%$ of putative transformants. It was also observed that transformed plantlets, on kanamycin selection, could easily be identified early during the rooting process by their production of root hairs, which was later confirmed by PCR analysis.

Pre-culture of explants was found crucial in this study, improving explant viability, reducing explant overgrowth from $A$. tumefaciens and assisting in the identification and removal of bacterial contaminated material prior to A. tumefaciens inoculation. Pre-induction of the regeneration capacity via a pre-culture treatment has been reported to improve the adhesion of $A$. tumefaciens during co-cultivation [29]. Pre-culture activates cell division and the phase of the cell-cycle has been shown to influence stable transformation [30] The presence of actively dividing cells improved cell competence for A. tumefaciens infection in regenerable tissue [29]. In Brassica rapa, seedling hypocotyls pre-cultured prior to exposure to $A$. tumefaciens showed greater shoot regeneration and improved transformation efficiency [31]. Similar improvements in regeneration and transformation efficiencies were reported for pre-cultured explants in tomato Solanum lycopersicum [32] and potato S. tuberosum [33].

The availability of good quality donor material for the initiation of explants was essential for maintaining P. vulgaris transformation efficiencies. Poor donor material or parent plants that had had a fungicidal application led to poor transformation efficiency in experiments (data not shown).

The addition of $\mathrm{AgNO}_{3}$ in co-cultivation medium improved transformation efficiency, helped to prevent A. tumefaciens overgrowth, and reduced browning of the explant material. The addition of $\mathrm{AgNO}_{3}$ was found effective in combination with Timentin for the control of $A$. tumefaciens in selection medium. Potent ethylene inhibitors, such as $\mathrm{AgNO}_{3}$, are added to plant media for enhancing shoot regeneration and preventing the negative effects of the gaseous plant hormone ethylene, extensively reviewed by Kumar et al. [34]. In addition, $\mathrm{AgNO}_{3}$ has been reported to promote callus proliferation [35], and improve root formation [36], and is widely used within plant tissue culture to aid plant regeneration in both dicot and monocot in vitro cultures [34]. In other species, $\mathrm{AgNO}_{3}$ inhibited shoot regeneration [37] which would indicate that the promotive function of $\mathrm{AgNO}_{3}$ on shoot regeneration is species-specific [38]. The addition of $\mathrm{AgNO}_{3}$ remarkably enhanced regeneration of P. vulgaris within tissue culture [14]. Silver ions play a major role in influencing somatic embryogenesis, shoot formation, and efficient root formation, all of which are prerequisites for successful plant transformation [34]. In addition, silver ions are effective inhibitors of microbial growth [39], $\mathrm{AgNO}_{3}$ was found to inhibit A. tumefaciens growth due to its bactericidal properties [40]. Effective control and or elimination of $A$. tumefaciens after cocultivation was reported when $\mathrm{AgNO}_{3}$ was used in combination with antibiotics [40]. Mendoza-De Gyves et al. [40] concluded that the advantages of adding $\mathrm{AgNO}_{3}$ within plant transformation systems were the inhibition of $A$. tumefaciens growth and the stimulation of plant regeneration.

\section{Conclusions}

In summary, we have developed two transformation systems for $P$. vulgaris, that will aid fundamental research into important traits in this species. The first system, vacuum infiltration of seedlings, enables the rapid testing of transgenes, in planta. This transient gene expression protocol is a useful tool for testing gene function and for reporter gene expression. The second transformation system allows the stable transformation of $P$. vulgaris using pedicel explants as its starting material and offers, for the first time, the methodology to allow the identification, and functional characterisation, of genes that are involved in the control of floral heteromorphy within Primula species.

\section{Materials and methods \\ Vectors and Agrobacterium strain}

Three vectors all containing the $35 S$ promoter [41] driving expression of the UidA (GUS) [42] gene; pJIT166 [22] containing the $2 \times 35 S$ promoter driving the original UidA (GUS) gene without an intron, pJIT166i containing the $2 \times 35 S$ promoter driving the UidA (GUS) plus the Pisum sativum Chalcone Synthase (CHS) intron1b (Fig. 1a) and pBRACT104 [21] containing the $35 S$ promoter driving the UidA (GUS) gene plus the Ricinus communis Catalase intron 1 (CAT1) were assessed, for use in Primula, by biolistic bombardment. 
The pBRACT100 series of vectors [21], containing the Neomycin Phosphotransferase II (NptII) gene, which confers in planta resistance to kanamycin, driven by the CaMV $35 S$ promoter $(35 S)$ were used for these studies. The pBRACT102 vector, containing the 35S::NptII and a Multiple Cloning Site (MSC), was modified to produce a reporter construct for use in Primula. The $2 \times 35 S$ promoter, $\beta$-glucuronidase (UidA/GUS) coding region containing the Pea (Pisum sativum) Chalcone Synthase (CHS) $1 b$ intron and the CaMV terminator were isolated as one $3744 \mathrm{bp}$ fragment from pJIT166i using Sac I and $P v u$ II. The fragment $(2 \times 35 S:: G U S$ intron::CaMV terminator) was subsequently cloned into the Sac I and Stu I sites of pBRACT102. The resulting plasmid was named pRIMULA105 (Fig. 1b).

The hypervirulent Agrobacterium tumefaciens strain AGL1 [43] containing pRIMULA105 was used to establish and optimise the plant transformation experiments. The vector pRIMULA105 was electroporated into A. tumefaciens AGL1 cells as described by Bartlett et al. [44] along with the helper plasmid pSoup [45]. A modified method of [46] was used to prepare standard A. tumefaciens inoculums for transformation as previously described by Bartlett et al. [44]. Equal quantities of the A.tumefaciens culture and $30 \%$ sterile glycerol were mixed and made into $200 \mu \mathrm{l}$ aliquots in $0.5 \mathrm{~mL}$ Eppendorf tubes. The standard inoculum aliquots were frozen by placing at $-80^{\circ} \mathrm{C}$ and stored.

\section{Particle bombardment for construct testing}

Particle bombardment was used to test the constitutive CaMV $35 S$ promoter and the UidA (GUS) reporter gene containing different introns in $P$. vulgaris. Young leaf material was excised from adult plants under aseptic conditions and surface sterilised as described by Hayta et al. [14]. The leaf material was then cut into approximately $1.6 \mathrm{~cm}^{2}$ sections and placed centrally onto solidified MS medium in $9 \mathrm{~cm}$ diameter Petri dishes. Three constructs were assessed pJIT166, pJIT166i and pBRACT104. Approximately $1 \mu \mathrm{g}$ of plasmid DNA was coated onto gold particles and bombarded into the leaf material using the method and parameters as described in Harwood and Smedley [47]. Each leaf section was bombarded twice, being turned 180 degrees between bombardments, three leaf sections were bombarded with each plasmid. The negative control consisted of leaf sections bombarded with gold particles without DNA. The petri dishes were sealed, and the leaf sections cultured for 3 days at $21 \pm 1{ }^{\circ} \mathrm{C}$ under cool white fluorescent light $\left(50 \mu \mathrm{mol} \mathrm{m} \mathrm{m}^{-2} \mathrm{~s}^{-1}\right)$ with a 16 -h light period per day prior to assessment by GUS assay.

\section{Histochemical GUS staining}

Histochemical staining of GUS activity was performed by incubating plant tissue at $37{ }^{\circ} \mathrm{C}$ overnight $(\sim 16 \mathrm{~h})$ in $1.0 \mathrm{mg} \mathrm{mL}^{-1}$ 5-bromo-4-chloro-3 indolylD-glucuronic acid, $0.1 \mathrm{M} \mathrm{Na}_{2} \mathrm{HPO}_{4}$ buffer $(\mathrm{pH}=7.0)$, $0.5 \mathrm{mM} \mathrm{K}_{3}\left(\mathrm{Fe}(\mathrm{CN})_{6}\right), 0.5 \mathrm{mM} \mathrm{K}_{4}\left(\mathrm{Fe}(\mathrm{CN})_{6}\right)$, and $10 \mathrm{mM}$ EDTA as described by Jefferson et al. [48]. The chlorophyll was removed from the plant tissues by immersing in $100 \%$ ethanol and incubating at room temperature $24 \pm 1{ }^{\circ} \mathrm{C}$ with gentle agitation for approximately $6 \mathrm{~h}$. The ethanol was changed twice during incubation. The GUSpositive plant tissues were examined with a bright field microscope (Leica MZ6, Cambridge, England) at a low magnification and photographed with a digital camera (Nikon Coolpix 4500, Japan).

\section{Transient expression system \\ Plant material and explant preparation}

Under aseptic conditions, $0.5 \mathrm{~g}$ of $P$. vulgaris seeds were surface sterilized in a $1.5 \mathrm{~mL}$ Eppendorf tube with $70 \%(\mathrm{v} / \mathrm{v})$ ethanol for $2 \mathrm{~min}$ and rinsed with sterile-distilled water, incubated for $20 \mathrm{~min}$ in $10 \%(\mathrm{v} / \mathrm{v})$ sodium hypochlorite (Fluka 71696) with a drop of Tween 20 (Sigma P-9416) with gently agitation. The seed were subsequently rinsed three times with distilled-sterile water. To aid seed germination, the seeds were pre-treated by applying filter sterilised gibberellic acid $\left(\mathrm{GA}_{3}\right)$ at $400 \mathrm{ppm}$ and incubated at room temperature $24 \pm 1{ }^{\circ} \mathrm{C}$ for $16 \mathrm{~h}$ in the dark. The $\mathrm{GA}_{3}$ solution was removed and discarded. Seeds were transferred to $100 \mathrm{~mL}$ Sterilin jars (5 per jar) containing $20 \mathrm{~mL}$ Seed Germination (SG) medium (described below). Seed germination took place in a controlled culture room at $21 \pm 1{ }^{\circ} \mathrm{C}$ under cool white fluorescent light $\left(50 \mu \mathrm{mol} \mathrm{m}{ }^{-2} \mathrm{~s}^{-1}\right)$ with a 16-h light period per day. Seedlings were cultured for approximately 4 weeks prior to infiltration.

\section{Media}

Seed Germination (SG) medium, Murashige and Skoog (MS) [49] basal medium containing 3\% (w/v) sucrose and solidified with $0.6 \%(\mathrm{w} / \mathrm{v})$ agar, without plant growth regulators.

\section{Preparation of Agrobacterium tumefaciens}

A $200 \mu \mathrm{L}$ aliquot of standard inoculum was removed from $-80{ }^{\circ} \mathrm{C}$ storage, added to $10 \mathrm{~mL}$ of $\mathrm{LB}$ liquid medium containing $25 \mu \mathrm{g} \mathrm{mL}{ }^{-1}$ kanamycin and $25 \mu \mathrm{g} \mathrm{mL} \mathrm{m}^{-1}$ rifampicin and incubated at $28^{\circ} \mathrm{C}$ shaken at $200 \mathrm{rpm}$ for $24 \mathrm{~h}$. Five hundred microliters of this culture were used to inoculate $50 \mathrm{~mL}$ of $\mathrm{LB}$ liquid medium supplemented with $25 \mu \mathrm{g} \mathrm{mL}^{-1}$ kanamycin, $25 \mu \mathrm{g} \mathrm{mL}{ }^{-1}$ rifampicin and $5 \mu \mathrm{M}$ acetosyringone (AS) incubated at $28^{\circ} \mathrm{C}$ and shaken 
$200 \mathrm{rpm}$ overnight $\sim 16 \mathrm{~h}$. The $A$. tumefaciens culture was transferred to $50 \mathrm{~mL}$ Falcon tubes $\left(25 \mathrm{~mL}^{-1}\right.$ tube) and centrifuged at $3100 \mathrm{rpm}$ for $10 \mathrm{~min}$ at $24{ }^{\circ} \mathrm{C}$, to pellet the bacteria. The supernatant was discarded and the bacterial pellets were resuspended in $10 \mathrm{mM} \mathrm{MgCl}_{2} \mathrm{pH} 5.8$ containing $100 \mu \mathrm{M}$ AS. The optical density of the infiltration buffer containing Agrobacterium cells was adjusted to 0.5 at $\mathrm{OD}_{600}$. Each $50 \mathrm{~mL}$ Falcon tube contained $25 \mathrm{~mL}$ infiltration buffer and the resuspended A. tumefaciens cells. The Falcon tubes were placed horizontally on a shaker and gently shaken at $120 \mathrm{rpm}$ at room temperature $24 \pm 1{ }^{\circ} \mathrm{C}$ for 4 to $5 \mathrm{~h}$. Immediately prior to seedling infiltration Silweet ${ }^{\circledR} \mathrm{L}-77$ was added to the A. tumefaciens cells to a final concentration of $0.01 \%$.

\section{Vacuum infiltration of Primula vulgaris seedlings}

Under aseptic conditions, between 5 and 7 in vitro grown seedlings were placed in a $50 \mathrm{~mL}$ Falcon tube containing $25 \mathrm{~mL}$ of $A$. tumefaciens suspension containing pRIMULA105 prepared in infiltration buffer. The open Falcon tube, in turn, was placed within a sterile desiccator attached to a vacuum pump within a laminar air-flow cabinet. A vacuum was drawn to $600 \mathrm{~mm} \mathrm{Hg}$ and held for $15 \mathrm{~min}$, the vacuum was released rapidly, and the procedure repeated four times over $1 \mathrm{~h}$. Following the four exposures to vacuum, the tube was left to sit at ambient air pressure for $20 \mathrm{~min}$. The bacterial suspension was discarded, and the seedlings were washed six times with sterile-distilled water to remove excess $A$. tumefaciens. The seedlings were transferred to a sterile $1 \mathrm{~L}$ Erlenmeyer flask containing $250 \mathrm{~mL}$ of liquid MS medium with $3 \%$ sucrose and incubated at room temperature with gentle agitation $(60 \mathrm{rpm})$. After $24 \mathrm{~h}$, filter sterilised cefotaxime was added to the MS medium at a final concentration of $250 \mathrm{mg} \mathrm{L}^{-1}$ to control $A$. tumefaciens growth. The seedlings were maintained in the liquid MS at room temperature with gentle agitation $(60 \mathrm{rpm})$ for a further 2 days $(48 \mathrm{~h})$. The seedlings were then assayed for GUS expression as described previously.

\section{Stable transformation of Primula vulgaris \\ Plant material and explant preparation}

Adult flowering plants of $P$. vulgaris were used as the initial explant source for this study. Parent plants were grown in 1 litre pots of peat-based multi-purpose compost (Erin Horticulture, Ireland-MPC60) in a glasshouse at $16 \pm 1{ }^{\circ} \mathrm{C}$ day and night, relative humidity (RH) $60 \%$ under natural light. Pedicels were harvested when the flower buds were closed and just showing the tips of the petals ( $\sim 1-2 \mathrm{~mm}$ of yellow showing). Under aseptic conditions within a laminar flow cabinet, Pedicels with the buds attached, were surface sterilized by immersion in $70 \%(\mathrm{v} / \mathrm{v})$ ethanol for $1 \mathrm{~min}$ and rinsed once with sterile-distilled water. This procedure was followed by immersion in $10 \%(\mathrm{v} / \mathrm{v})$ bleach $(10 \%$ sodium hypochlorite; Fluka 71696) with a drop of Tween 20 (Sigma P-9416), for $12 \mathrm{~min}$, followed by six rinses with distilled-sterile water. Tissue damaged by the bleach was excised and discarded before cutting each pedicel into $0.3-0.5 \mathrm{~cm} \mathrm{sec-}$ tional explants, the flower buds were discarded. Explants were placed horizontally on PCI medium as a pre-cultivation treatment before inoculation. Twenty explants were cultured per $9 \mathrm{~cm}$ Petri plate. These samples were cultured under low light conditions $\left(12.1 \mu \mathrm{mol} \mathrm{m} \mathrm{m}^{-2} \mathrm{~s}^{-1}\right)$ at $21 \pm 1{ }^{\circ} \mathrm{C}$ with a 16 -h photoperiod. The explants were cultured for 2 weeks on PCI medium prior to inoculation with $A$. tumefaciens containing the relevant Ti plasmid.

\section{Media}

All media were prepared at double $(2 \mathrm{X})$ the final required concentration, adjusted to $\mathrm{pH} 5.8$ and filter sterilized. Phytagel (catalog no. P8169; Sigma-Aldrich Co., St. Louis, MO, USA), used as the gelling agent, was also prepared at double final required concentration, autoclaved, and stored at room temperature until required. To prepare the final medium, both double-concentration Phytagel and media components were heated to $60{ }^{\circ} \mathrm{C}$ in a water bath, then mixed together, and poured into $9 \mathrm{~cm}$ diameter petri dishes or Sterilin jars.

Primula Callus Induction (PCI) medium [14], consisted of Gamborg (B5) [50] macro salts with $965.77 \mathrm{~g} \mathrm{~L}^{-1} \mathrm{KNO}_{3}, 1 / 2 \mathrm{MS}$ micro salts and MS vitamins, $20 \mu \mathrm{M} \mathrm{AgNO}_{3}, 3 \mathrm{mg} \mathrm{L}^{-1}$ thidizuron (TDZ), $0.3 \mathrm{mg} \mathrm{L}^{-1}$ $\alpha$-naphthaleneacetic acid (NAA), $30 \mathrm{~g} \mathrm{~L}^{-1}$ Maltose, $3.5 \mathrm{~g} \mathrm{~L}^{-1}$ phytagel.

Primula rooting medium (PRM) [14], consisted of woody plant medium (WPM) (Lloyd and McCown 1981) basal salts with $2 \%$ sucrose, $0.5 \mathrm{mg} \mathrm{L}^{-1}$ indole-3-butyric acid (IBA), solidified with $1.75 \mathrm{~g} \mathrm{~L}^{-1}$ Phytagel.

\section{Preparation of Agrobacterium tumefaciens}

One hundred microliters of standard inoculum was transferred to $10 \mathrm{~mL}$ of MG/L [51] (tryptone, $2.5 \mathrm{~g} \mathrm{~L}^{-1}$ yeast, $100 \mathrm{mg} \mathrm{L}^{-1} \mathrm{NaCl}, 5 \mathrm{~g} \mathrm{~L}^{-1}$ mannitol, $1 \mathrm{~g} \mathrm{~L}^{-1} \mathrm{Glu}$ tamic acid, $250 \mathrm{mg} \mathrm{L}^{-1} \mathrm{KH}_{2} \mathrm{PO}_{4}, 100 \mathrm{mg} \mathrm{L}^{-1} \mathrm{MgSO}_{4}$, $1 \mu \mathrm{g} \mathrm{L}^{-1}$ Biotin. $\mathrm{pH}=7$ ) liquid medium without antibiotics. This was grown overnight $\sim 16 \mathrm{~h}$ at $28{ }^{\circ} \mathrm{C}$ shaken at $200 \mathrm{rpm}$. The bacterial optical density was adjusted to 1.0 at $\mathrm{OD}_{600}$ using sterile $\mathrm{MG} / \mathrm{L}$ prior to explant inoculation.

\section{Determination of sensitivity of Primula vulgaris to the selective agent kanamycin}

Pedicel explants that had begun to swell and cells divide following precultured on PCI medium for 4 weeks were used to assess the sensitivity of $P$. vulgaris to the selective agent kanamycin. Kanamycin was included into the 
PCI medium at different concentrations: 0, 100, 125, 150, $200 \mathrm{mg} \mathrm{L}^{-1}$. Fifteen precultured explants were used per $9 \mathrm{~cm}$ Petri plate with 3 petri plates per treatment and cultured at $21 \pm 1{ }^{\circ} \mathrm{C}$ under low light conditions $\left(12.1 \mu \mathrm{mol} \mathrm{m}^{-2} \mathrm{~s}^{-1}\right)$ with a $16-\mathrm{h}$ photoperiod. The material was subcultured, after 2 weeks, onto fresh PCI with the different kanamycin concentrations. The plant material was visually assessed and treatments compared after 3 weeks of culture.

\section{Explant inoculation with Agrobacterium tumefaciens}

Under aseptic conditions the pre-cultured pedicel explants were immersed fully in the MG/L-A. tumefaciens suspension and incubated at room temperature for $5 \mathrm{~min}$. The explants were blot dried on sterile filter paper to remove excess $A$. tumefaciens before transferring, 15 per plate, to co-cultivation medium consisting of PCI supplemented with $200 \mu \mathrm{M}$ AS and $10 \mu \mathrm{M} \mathrm{AgNO}_{3}$. The plates were co-cultured in the dark at $23 \pm 1{ }^{\circ} \mathrm{C}$ for 3 days. After co-cultivation, the explants were transferred to PCI medium containing $160 \mathrm{mg} \mathrm{L}^{-1}$ Timentin for elimination of $A$. tumefaciens and $20 \mu \mathrm{M} \mathrm{AgNO}$ for a 5 day resting period. The cultures were then incubated at $21 \pm 1{ }^{\circ} \mathrm{C}$ under cool white florescent light $\left(100 \mathrm{mmol} \mathrm{m}^{-2} \mathrm{~s}^{-1}\right)$ with a 16-h photoperiod.

\section{Selection and plantlet regeneration}

After a 5-day resting period, the explants were transferred onto selection medium consisting of PCI medium containing $20 \mu \mathrm{M} \mathrm{AgNO}_{3}$, Timentin $\left(160 \mathrm{mg} \mathrm{L}^{-1}\right)$ and kanamycin $\left(125 \mathrm{mg} \mathrm{L}^{-1}\right)$. The explants were subcultured onto fresh medium fortnightly. After 4-6 weeks the callus explants began to produce adventitious shoots. Shoots longer than $10 \mathrm{~mm}$ were isolated and transferred individually to $100 \mathrm{~mL}$ Sterilin jars containing $20 \mathrm{~mL}$ of PRM supplemented with $25 \mathrm{mg} \mathrm{L}^{-1}$ kanamycin and $160 \mathrm{mg} \mathrm{L}^{-1}$ Timentin. Plantlets were maintained for 4-6 weeks in Sterilin jars, incubated at $21 \pm 1{ }^{\circ} \mathrm{C}$ under cool white florescent light $\left(100 \mathrm{mmol} \mathrm{m} \mathrm{m}^{-2} \mathrm{~s}^{-1}\right)$ with a 16-h photoperiod.

\section{Transfer and establishment in soil}

Well-rooted, healthy looking plantlets were transferred to multi-purpose compost in $5 \mathrm{~cm}$ square cells within propagation trays. Plants were covered with clear plastic propagator lids for approximately 2 weeks to maintain high humidity around them while they established in soil. Plants were grown in a controlled environment room at $18 \pm 1{ }^{\circ} \mathrm{C}$ day and $15 \pm 1{ }^{\circ} \mathrm{C}$ night temperatures, $75 \%$ relative humidity with light intensity of $250 \mu \mathrm{mol} \mathrm{m} \mathrm{m}^{-2} \mathrm{~s}^{-1}$ provided by metal halide lamps (HQI) supplemented with tungsten bulbs with a $16 \mathrm{~h}$ photoperiod.

\section{DNA extraction}

Leaf samples with a mass of approximately $100 \mathrm{mg}$ were harvested into $1.5 \mathrm{~mL}$ Eppendorf tubes and flash frozen using liquid nitrogen. If DNA extraction could not be carried out immediately then the leaf material was stored at $-80^{\circ} \mathrm{C}$. The DNA was extracted from the leaf material using the Qiagen DNeasy plant mini kit (Cat No. 69106) following the manufacturer's instructions. The DNA concentrations were assessed using the Nanodrop ND-1000 spectrophotometer.

\section{Polymerase chain reaction (PCR)}

Polymerase chain reactions were prepared using RedTaq ReadyMix PCR Reaction Mix (Sigma-Aldrich R2523) with a reaction total volume of $20 \mu \mathrm{l}$. Each reaction comprised $10 \mu \mathrm{l}$ RedTaq ReadyMix PCR Reaction Mix, $1 \mu \mathrm{l}$ $(10 \mathrm{mM})$ of each forward and reverse primers, $50 \mathrm{ng}$ of plant genomic DNA, made up to a total volume of $20 \mu \mathrm{l}$ by sterile laboratory grade water. The specific forward $(\mathrm{F})$ and reverse (R) PCR primers used are listed in Table 1.

The NptII PCR was used to identify transgenic plant material. The reaction conditions were as follows: denaturation at $94{ }^{\circ} \mathrm{C}$ for $5 \mathrm{~min}$, then 30 cycles of $94{ }^{\circ} \mathrm{C}, 30 \mathrm{~s}$ denaturation; $60^{\circ} \mathrm{C}$ for $30 \mathrm{~s}$ annealing and $72{ }^{\circ} \mathrm{C}$ for $1 \mathrm{~min}$ $15 \mathrm{~s}$ extension and a final extension at $72{ }^{\circ} \mathrm{C}$ for $5 \mathrm{~min}$. The expected amplicon size for NptII PCR was $700 \mathrm{bp}$.

PCR analysis for the Agrobacterium tumefaciens Ti VirD2 gene was performed on all plant genomic DNA extractions to check that there was no remaining Agrobacterium contamination. The VirD2 PCR conditions were as follows: denaturation at $94{ }^{\circ} \mathrm{C}$ for $5 \mathrm{~min}$, then 30 cycles of $30 \mathrm{~s}$ at $94{ }^{\circ} \mathrm{C} ; 30 \mathrm{~s}$ annealing at $55^{\circ} \mathrm{C}$ and $1 \mathrm{~min}$ extension at $72{ }^{\circ} \mathrm{C}$, and a final extension at $72{ }^{\circ} \mathrm{C}$ for $5 \mathrm{~min}$. The expected VirD2 amplicon size was $487 \mathrm{bp}$.

The quality of the genomic DNA used for this study was tested using primers specific for the endogenous $P$. vulgaris Actin gene. The Pv Actin reaction conditions were

Table 1 List of PCR primers used in the study

\begin{tabular}{llll}
\hline Gene/PCR & Primer left & Primer right & Description \\
\hline nptll & GAG GCT ATT CGG CTA TGA CTG G & ATC GGG AGC GGC GAT ACC GTA & NPTII gene-specific primers to identify transgenic material \\
VirD2 & TCA AGT AAT CAT TCG CATTGT GCC & GCC GTG ACG AAG TGA AAT CTC & VirD2 gene-specific primers to identify Agrobacterium \\
Pvactin & GTG ATA ATG GGA CCG GAA TG & TGC TTC CGT CAA CAA AAC AG & Primula vulgaris-Actin used to assess genomic DNA quality \\
\hline
\end{tabular}


as follows: denaturation at $95^{\circ} \mathrm{C}$ for 3 min, then 35 cycles of $30 \mathrm{~s}$ at $95{ }^{\circ} \mathrm{C}, 30 \mathrm{~s}$ annealing at $55^{\circ} \mathrm{C}$ and $30 \mathrm{~s}$ extension at $72{ }^{\circ} \mathrm{C}$, and a final extension at $72{ }^{\circ} \mathrm{C}$ for $5 \mathrm{~min}$. The expected amplicon for Pv Actin PCR was $500 \mathrm{bp}$.

Positive, negative and water controls were included in all PCR analyses. The amplified products were resolved on a $1 \%$ agarose gel containing ethidium bromide at $0.1 \mu \mathrm{g} \mathrm{ml}^{-1}$ in $0.5 \times \mathrm{TBE}$ buffer.

\section{Southern blot analysis}

$10 \mu \mathrm{g}$ DNA was digested with 30 units of HindIII or Eco $\mathrm{RI}$ (both of which cut once in the T-DNA) with $3 \mu \mathrm{L} 10 \mathrm{X}$ buffer in a total volume of $30 \mu \mathrm{L}$ at $37{ }^{\circ} \mathrm{C}$ (Invitrogen/ Life Technologies) overnight $\sim 16 \mathrm{~h}$. The digested DNA was separated on a $0.8 \%$ agarose gel at $3 \mathrm{~V} / \mathrm{cm}$ overnight. An alkaline Southern blot was assembled [52] and the DNA transferred onto a Hybond-N+membrane (Amersham) by capillary transfer according to the manufacturer's instructions. Previously-PCR amplified, ${ }^{32} \mathrm{P}$ randomly labelled probe from the coding region of the NptII marker gene (700 bp) was used for hybridisation. The probe had been amplified using the primers nptII_F and nptII_R (Table 1) for NptII (see above section PCR). Labelling was carried out using a Ready-To-Go DNA labelling Beads (-dCTP) (GE Healthcare, Product code: 27-9240-01). Pre-hybridisation and hybridisation were carried out at $42{ }^{\circ} \mathrm{C}$ overnight in hybridisation buffer containing $50 \%$ formamide, $5 \times$ SSC, $5 \times$ Denhardt solution and $0.5 \%$ SDS. The membrane blot was then washed three times in a solution containing $2 \times$ SSC and $0.1 \%$ SDS at $42{ }^{\circ} \mathrm{C}$. After the final wash, the membrane was sealed in a plastic bag and Kodak Biomax MR film was exposed to it for 4 days at room temperature $24 \pm 1{ }^{\circ} \mathrm{C}$. The film was developed using a medical film processor (SRX-101A, Konica Minolata Inc., Japan) and the image scanned and digitalised.

\section{Analysis of transgene inheritance}

Five $\mathrm{T}_{0}$ plants were out crossed to produce seed. Under aseptic conditions, these seed were surface sterilised as previously described and germinated on MS medium supplemented with $125 \mathrm{mg} \mathrm{L^{-1 }}$ kanamycin within $100 \mathrm{~mL}$ Sterilin jars ( 10 per jar). Seed germination took place in a controlled culture room at $21 \pm 1^{\circ} \mathrm{C}$ under cool white fluorescent light $\left(50 \mu \mathrm{mol} \mathrm{m} \mathrm{m}^{-2} \mathrm{~s}^{-1}\right)$ with a 16 -h light period per day. Further analysis of transgene inheritance was obtained by crossing a $T_{0}$ transgenic plant to produce seed and progeny grown to produce $T_{1}$ plants. Leaves were collected from four $\mathrm{T}_{1}$ progeny, and genomic DNA was extracted. Transgene inheritance (NptII gene) was assessed by performing PCR analysis using the NptII gene specific primers and Southern analysis as described in the above section.

\section{Authors' contributions}

PMG conceived the study and coordinated this project with WH. SH performed the transformation experiments, carried out data assessment and drafting the paper. MAS performed molecular cloning and contributed the data analysis. JL provided the plant materials, carried out Southern blot hybridisation and contributed the analysis. WH contributed to the study's design and project coordination. All authors read and approved the final manuscript.

\section{Author details \\ 1 School of Biological Sciences, University of East Anglia, Norwich Research Park, Norwich NR4 7UH, UK. ${ }^{2}$ John Innes Centre, Norwich Research Park, Norwich NR4 7UH, UK. ${ }^{3}$ The Earlham Institute, Norwich Research Park, Nor- wich NR4 7UH, UK.}

\section{Acknowledgements}

We are grateful to the University of East Anglia for support and the John Innes Centre for hosting PGs laboratory under the UEA-JIC Norwich Research Park collaboration. We thank Pam Wells for horticultural support and Andrew Davis of JIC photographic services for photography.

\section{Competing interests}

The authors declare that they have no competing interests.

Availability of data and materials

The datasets supporting the conclusions are included within the article.

Consent for publication

All the authors are in their consent for publication of this article.

Ethics approval and consent to participate

Not applicable.

\section{Funding}

This work was supported by Biotechnology and Biological Sciences Research Council (BBSRC) BB/H019278/2 and The Gatsby Charitable Foundation.

\section{Publisher's Note}

Springer Nature remains neutral with regard to jurisdictional claims in published maps and institutional affiliations.

Received: 16 August 2018 Accepted: 17 October 2018

Published online: 26 October 2018

References

1. Narusaka Y, Narusaka M, Yamasaki S, Iwabuchi M. Methods to transfer foreign genes to plants. In: Zden Y, editor. Transgenic plants_advances and limitations. Rijeka: InTech; 2012.

2. Bakshi S, Sadhukhan A, Mishra S, Sahoo L. Improved Agrobacterium-mediated transformation of cowpea via sonication and vacuum infiltration. Plant Cell Rep. 2011;30(12):2281-92.

3. Rajesh PN, Muehlbauer FJ, McPhee KE. Stability analysis of chickpea large genomic DNA inserts in Agrobacterium. ICRISAT. 2007;3(1):2.

4. Wu H-Y, Liu K-H, Wang Y-C, Wu J-F, Chiu W-L, Chen C-Y, Wu S-H, Sheen J, Lai E-M. AGROBEST: an efficient Agrobacterium-mediated transient expression method for versatile gene function analyses in Arabidopsis seedlings. Plant Methods. 2014;10(1):19.

5. Li J, Park E, von Arnim AG, Nebenführ A. The FAST technique: a simplified Agrobacterium-based transformation method for transient gene expression analysis in seedlings of Arabidopsis and other plant species. Plant Methods. 2009;5(1):6.

6. Trieu AT, Burleigh SH, Kardailsky IV, Maldonado-Mendoza IE, Versaw WK, Blaylock LA, Shin H, Chiou T-J, Katagi H, Dewbre GR, Weigel D, Harrison MJ. Transformation of Medicago truncatula via infiltration of seedlings or flowering plants with Agrobacterium. Plant J. 2000;22(6):531-41.

7. Morozowska M, Wesołowska M. In vitro clonal propagation of Primula veris $\mathrm{L}$. and preliminary phytochemical analysis. Acta Biol Cracov Bot. 2004:46:169-75. 
8. Benson EE, Danaher JE, Pimbley IM, Anderson CT, Wake JE, Daley S, Adams LK. In vitro micropropagation of Primula scotica: a rare Scottish plant. Biodivers Conserv. 2000;9(6):711-26.

9. Hamidoghli Y, Noroozi Sharaf AR, Zakizadeh H. Organogenesis from seedling derived leaf explants of primrose (Primula heterochroma Stapf.) as a scarce Iranian plant. Aust J Crop Sci. 2011;5(4):391.

10. Shimada T, Matsushita T, Otani M. Plant regeneration from leaf explants of Primula cuneifolia var. hakusanensis,"Hakusan-kozakura". Plant Biotechnol. 1997:14(1):47-50

11. Takihira M, Otani M, Tsuchiya S, Shimada T. Plant regeneration from leaf explants of auricula cultivars (Primula $\times$ pubescens Jacq.). Plant Biotechnol. 2007:24(4):425-7.

12. Merkle S, Götz EM: Micropropagation of inbred lines of Primula acaulis for breeding purposes. In: Abstract 7th international congress on plant tissue and cell culture, 1990, p 116

13. Schween G, Schwenkel H-G. Effect of genotype on callus induction, shoot regeneration, and phenotypic stability of regenerated plants in the greenhouse of Primula ssp. Plant Cell Tissue Organ Cult. 2003;72(1):53-61.

14. Hayta S, Smedley MA, Li J, Harwood WA, Gilmartin PM. Plant regeneration from leaf-derived callus cultures of primrose (Primula vulgaris). HortScience. 2016;51(5):558-62.

15. Li J, Cocker JM, Wright J, Webster MA, McMullan M, Dyer S, Swarbreck D, Caccamo M, Oosterhout CV, Gilmartin PM. Genetic architecture and evolution of the $\mathrm{S}$ locus supergene in Primula vulgaris. Nat Plants. 2016;2(12):16188

16. Darwin C. On the two forms, or dimorphic condition, in the species of primula, and on their remarkable sexual relations. J Proc Linn Soc Lond Bot. 1862;6(22):77-96.

17. Gilmartin PM. On the origins of observations of heterostyly in Primula. New Phytol. 2015;208(1):39-51.

18. Li J, Webster MA, Smith MC, Gilmartin PM. Floral heteromorphy in Primula vulgaris: progress towards isolation and characterization of the $\mathrm{S}$ locus. Ann Bot. 2011;108(4):715-26.

19. Lloyd DG, Webb CJ. The evolution of heterostyly. In: Barrett SCH, editor. Evolution and function of heterostyly. Berlin: Springer; 1992. p. 151-78.

20. Richards AJ. Plant breeding systems. New York: Springer; 1997.

21. Smedley MA, Harwood WA. Gateway(R)-compatible plant transformation vectors. Method Mol Biol (Clifton, NJ). 2015;1223:3-16.

22. Guerineau F, Lucy A, Mullineaux P. Effect of two consensus sequences preceding the translation initiator codon on gene expression in plant protoplasts. Plant Mol Biol. 1992;18(4):815-8.

23. Weaver J, Goklany S, Rizvi N, Cram EJ, Lee-Parsons CWT. Optimizing the transient fast agro-mediated seedling transformation (FAST) method in Catharanthus roseus seedlings. Plant Cell Rep. 2014;33(1):89-97.

24. Huu CN, Kappel C, Keller B, Sicard A, Takebayashi Y, Breuninger H, Nowak MD, Bäurle I, Himmelbach A, Burkart M, Ebbing-Lohaus T, Sakakibara H, Altschmied L, Conti E, Lenhard M. Presence versus absence of CYP734A50 underlies the style-length dimorphism in primroses. eLife. 2016;5:e17956.

25. Manavella PA, Chan RL. Transient transformation of sunflower leaf discs via an Agrobacterium-mediated method: applications for gene expression and silencing studies. Nat Protocols. 2009:4(11):1699-707.

26. Fister AS, Shi Z, Zhang Y, Helliwell EE, Maximova SN, Guiltinan MJ. Protocol: transient expression system for functional genomics in the tropical tree Theobroma cacao L. Plant Methods. 2016;12(1):19.

27. Barrett SC. Evolution and function of heterostyly. Berlin: Springer; 1992.

28. Franklin-Tong VE. Self-incompatibility in flowering plants. Evolution, diversity, and mechanisms. 2008. p. 305.

29. Piqueras A, Alburquerque N, Folta KM. Explants used for the generation of transgenic plants. In: Kole C, Michler CH, Abbott AG, Hall TC, editors. Transgenic crop plants: principles and development. Berlin: Springer; 2010. p. 31-56.

30. Yadav SK, Katikala S, Yellisetty V, Kannepalle A, Narayana JL, Maddi V, Mandapaka M, Shanker AK, Bandi V, Bharadwaja KP. Optimization of Agrobacterium mediated genetic transformation of cotyledonary node explants of Vigna radiata. SpringerPlus. 2012;1 (1):59.
31. Baskar V, Gangadhar BH, Park SW, Nile SH. A simple and efficient Agrobacterium tumefaciens-mediated plant transformation of Brassica rapa ssp. pekinensis. 3. Biotech. 2016;6(1):88.

32. Rai GK, Rai NP, Kumar S, Yadav A, Rathaur S, Singh M. Effects of explant age, germination medium, pre-culture parameters, inoculation medium, $\mathrm{pH}$, washing medium, and selection regime on Agrobacterium-mediated transformation of tomato. Vitro Cell Dev Biol Plant. 2012:48(5):565-78.

33. Chakravarty B G, Wang-Pruski G. Rapid regeneration of stable transformants in cultures of potato by improving factors influencing Agrobacterium-mediated transformation. Adv Biosci Biotechnol. 2010;1:409-16.

34. Kumar V, Parvatam G, Ravishankar GA. $\mathrm{AgNO}_{3}$ - a potential regulator of ethylene activity and plant growth modulator. Electron J Biotechnol. 2009:12:1-15.

35. Fei S, Read PE, Riordan TP. Improvement of embryogenic callus induction and shoot regeneration of buffalograss by silver nitrate. Plant Cell Tissue Organ Cult. 2000;60(3):197-203.

36. Khalafalla MM, Hattori K. Ethylene inhibitors enhance in vitro root formation on faba bean shoots regenerated on medium containing thidiazuron. Plant Growth Regul. 2000;32(1):59-63.

37. Bandyopadhyay S, Cane K, Rasmussen G, Hamill JD. Efficient plant regeneration from seedling explants of two commercially important temperate eucalypt species-Eucalyptus nitens and E. globulus. Plant Sci. 1999;140(2):189-98

38. Sarropoulou VD, Therios TK. Effect of the ethylene inhibitors silver nitrate, silver sulphate and cobalt chloride on micropropagation and biochemical parameters in the cherry rootstocks CAB-6P and Gisela 6. Turk J Biol. 2016:40(3):670-83.

39. Lin YSE, Vidic RD, Stout JE, McCartney CA, Yu VI. Inactivation of Mycobacterium avium by copper and silver ions. Water Res. 1998;32(7):1997-2000.

40. Mendoza-De Gyves E, Picarella ME, Ruiu F, Teixeira Da Silva JA, Rouphael Y, Muleo R, Rugini E. Inhibition of Agrobacterium tumefaciens growth by silver nitrate. Int J Plant Dev Biol. 2010;4(1):64-7.

41. Odell JT, Nagy F, Chua NH. Identification of DNA sequences required for activity of the cauliflower mosaic virus 355 promoter. Nature. 1985:313(6005):810-2.

42. Jefferson RA. The GUS reporter gene system. Nature. 1989;342:837.

43. Lazo GR, Stein PA, Ludwig RA. A DNA transformation-competent Arabidopsis genomic library in Agrobacterium. Biotechnology (Nature Publishing Company). 1991;9(10):963-7.

44. Bartlett JG, Alves SC, Smedley M, Snape JW, Harwood WA. High-throughput Agrobacterium-mediated barley transformation. Plant Methods. 2008:4(1):22.

45. Hellens RP, Edwards EA, Leyland NR, Bean S, Mullineaux PM. pGreen: a versatile and flexible binary Ti vector for Agrobacterium-mediated plant transformation. Plant Mol Biol. 2000;42:819-32.

46. Tingay S, McElroy D, Kalla R, Fieg S, Wang M, Thornton S, Brettell R. Agrobacterium tumefaciens-mediated barley transformation. Plant J. 1997;11(6):1369-76.

47. Harwood WA, Smedley MA. Barley transformation using biolistic techniques. Methods Mol Biol. 2009;478:125-36.

48. Jefferson RA, Kavanagh TA, Bevan MW. GUS fusions: beta-glucuronidase as a sensitive and versatile gene fusion marker in higher plants. EMBO J. 1987:6(13):3901-7.

49. Murashige T, Skoog F. A revised medium for rapid growth and bio Assays with tobacco tissue cultures. Physiol Plant. 1962;15(3):473-97.

50. Gamborg OL, Miller RA, Ojima K. Nutrient requirements of suspension cultures of soybean root cells. Exp Cell Res. 1968;50(1):151-8.

51. Garfinkel DJ, Nester EW. Agrobacterium tumefaciens mutants affected in crown gall tumorigenesis and octopine catabolism. J Bacteriol. 1980;144(2):732-43.

52. Southern EM. Detection of specific sequences among DNA fragments separated by gel electrophoresis. J Mol Biol. 1975;98(3):503-17. 